\author{
JURNAL LAMPUHYANG \\ LEMBAGA PENJAMINAN MUTU \\ STKIP AGAMA HINDU AMLAPURA
}

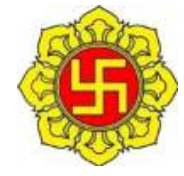

Volume 12 Nomor 2 Juli 2021

p-ISSN: 2087-0760; e-ISSN: 2745-5661

https://e-journal.stkip-amlapura.ac.id

\title{
Penerapan Model Pembelajaran Discovery Learning dengan Media Zoom untuk Meningkatkan Kemampuan Membaca Pemahaman Bahasa Inggris pada SMK Negeri 1 Amlapura
}

\author{
Kade Restika Dewi \\ STKIP Agama Hindu Amlapura \\ restika@stkip-amlapura.ac.id
}

\begin{tabular}{|l|l|l|}
\hline Direvisi: 23 Juni 2021 & Diterima: 29 Juni 2021 & Diterbitkan: 1 Juli 2021 \\
\hline
\end{tabular}

\begin{abstract}
Abstrak: Penelitian ini merupakan penelitian tindakan yang bertujuan untuk mengetahui sejauh mana penerapan model pembelajaran discovery learning dengan media zoom dapat meningkatkan kemampuan membaca pemahaman Bahasa Inggris siswa kelas XI PH 4 SMKN 1 Amlapura tahun pelajaran 2020/2021. Penelitian ini dilakukan dalam 2 (dua) siklus. Subjek penelitian ini adalah siswa kelas XI PH 4 SMKN 1 Amlapura tahun pelajaran 2020/2021 yang berjumlah 32 orang. Objek penelitian ini adalah peningkatan kemampuan membaca siswa SMKN 1 Amlapura kelas XI PH 4 dengan menggunakan model pembelajaran discovery learning dengan media zoom meeting. Metode pengumpulan data dilakukan dengan observasi dan tes. Data yang telah terkumpul dari hasil tes dianalisis dengan menggunakan analisis diskriptif kuantitatif yang berlangsung setiap akhir siklus. Berdasarkan hasil data, dapat dilihat terjadinya peningkatan kemampuan membaca pemahaman Bahasa Inggris siswa kelas XI PH 4 SMKN 1 Amlapura. Pada refleksi awal nilai rata-rata kemampuan membaca pemahaman Bahasa Inggris siswa yaitu 58 dengan ketuntasan 48\%, meningkat menjadi 70,40 dengan ketuntasan $80,76 \%$ pada siklus 1 , dan pada siklus 2 meningkat lagi sedikit menjadi 71,11 dengan ketuntasan $81,48 \%$.
\end{abstract}

Kata Kunci: model pembelajaran discovery learning, media zoom, kemampuan membaca pemahaman Bahasa Inggris

Abstract: This research was an action research that aimed at determining the extent to which the implementation of the discovery learning model with zoom media can improve the reading comprehension of English students of class XI PH 4 SMKN 1 Amlapura in the 2020/2021 academic year. This research was conducted in 2 (two) cycles. The subjects of this study were 32 class XI PH 4 students of SMKN 1 Amlapura in the academic year $2020 / 2021$. The object of this research was to increase the reading ability of students of SMKN 1 Amlapura class XI PH 4 using discovery learning model with zoom meeting media. The method of data collection was done by observation and tests. The data that had been collected from the test results were analyzed using quantitative descriptive 
analysis which took place at the end of each cycle. Based on the results of the data, it could be seen that there was an increase in the reading comprehension of English class XI PH 4 students of SMKN 1 Amlapura. In the initial reflection, the average value of students' reading comprehension in English was 58 with $48 \%$ completeness, increased to 70.40 with $80.76 \%$ completeness in cycle 1 , and in cycle 2 increased slightly to 71.11 with 81 completeness, $48 \%$.

Keywords: discovery learning model, zoom media, reading comprehension

\section{PENDAHULUAN}

\subsection{Latar Belakang Masalah}

$$
\text { Di era globalisasi seperti }
$$

sekarang ini, segala proses interaksi dan integrasi antara orang, perusahaan, maupun negara di seluruh dunia terjadi begitu cepat dan seolah tak berjarak. Semua orang diseluruh dunia bisa mengakses informasi ataupun berinteraksi dengan mudah. Pada era ini terjadi perkembangan yang sangat pesat dalam berbagai bidang, seperti IPTEK, ekonomi, politik, budaya, serta pendidikan.

Dampak dari perkembangan tersebut adalah terjadinya persaingan global atau persaingan dunia. Semua negara di dunia berlomba-lomba untuk menjadi yang terbaik. Untuk mampu bersaing di era globalisasi, sumber daya manusia yang bermutu adalah syarat yang mutlak. Sumber Daya Manusia (SDM) yang bermutu merupakan ujung tombak kemajuan suatu bangsa. SDM yang bermutu adalah sumber daya manusia yang memiliki pengetahuan (knowledge), keterampilan (skill) serta yang tidak kalah pentingnya adalah yang memiliki moral, mental, serta karakter (attitude) yang baik.

Pendidikan merupakan ujung tombak dalam mencetak SDM yang berkualitas dan bermutu,. Pendidikan menurut Ki Hajar Dewantara merupakan proses memanusiakan manusia. Pendidikan harus mampu menciptakan manusia yang berpengetahuan, berketerampilan dan berkarakter.

Agar mampu bersaing di era globalisasi, Bahasa Inggris adalah bahasa yang wajib dikuasai. Terlebih lagi untuk menghadapi AFTA (ASEAN Free Trade Area), APEC (Asia-Pacific Economic Cooperation) serta MEA (Masyarakat Ekonomia Asean). Untuk menghadapi itu, Bahasa Inggris merupakan bahasa yang wajib dikuasai.

Apapun profesi seseorang nantinya, untuk mampu bersaing di era globalisasi, Bahasa Inggris adalah 
bahasa yang wajib dikuasai. Bahasa Inggris diajarkan mulai dari sekolah dasar hingga perdosenan Tinggi. Apapun jurusan yang diambil oleh mahasiswa, Bahasa Inggris selalu menjadi mata kuliah wajib. Terlebih lagi dengan diterapkannya kurikulum berstandar KKNI.

Setiap orang di era ini diharapkan mampu berkomunikasi meggunakan Bahasa Inggris baik secara lisan maupun tulisan. Banyak orang yang bisa berhahasa Inggris secara lisan, menggalami kesulitan ketika diminta menulis dengan bahasa Inggris. Seperti misalnya untuk menulis memo atau pun pesan singkat dengan Bahasa Inggris.

Namun, memasuki tahun 2020, dunia digemparkan oleh virus mematikan yang berasal mula dari Cina. Dan dalam waktu sekejam WHO sudah mengumumkan bahwa virus tersebut sudah menjadi pandemic. Tepat 16 Maret 2020, Indonesia memasang alarm terhadap penyebaran virus corona atau lebih dikenal Covid-19. Hal tersebut berdampak pada segala lini kehidupan, tidak terkecuali pendidikan. Akibatnya, semua siswa belajar di rumah. Social distancing diterapkan dimana-mana, termasuk juga di sekolah. Guru mengajar dari rumah dan siswa pun belajar dari rumah.

Teknologi memegang peranan penting dalam hal ini. Guru mengajar dan siswa belajar dihubungkan oleh teknologi. Seperti halnya di SMKN 1 Amlapura, pada awal masa pandemi guru dan siswa diberi kebebasan memilih platform pembelajaran jarak jauh. Sebagian besar memilih whatsapp. Whatsapp menjadi penghubung antara materi yang ingin disampaikan guru kepada siswa. Melalui whatsap guru mengirimkan file materi serta penugasan kepada siswa.

Hal tersebut tak jarang menimbulkan keluhan-keluhan. Siswa mengeluh tidak paham materi karena tidak dijelaskan langsung oleh guru, kuota habis tidak bisa mengikuti pembelajaran, orang tua dirumahkan karena sektor ekonomi dan pariwisata juga berdampak Covid-19 ini dan masih banyak keluhan lainnya.

Oleh karena itu timbulah masalah, seperti hanya 25 siswa yang aktif mengikuti pembelajaran dari jumlah 32 siswa, minat belajar siswa menurun, alhasil kemampuan membaca pemahaman Bahasa Inggris siswa juga menurun. Hal tersebut dapat dilihat dari data kelas XI PH 4. Dari 25 siswa yang 
aktif mengikuti pelajaran, rata-rata nilai kemampuan membaca pemahaman Bahasa Inggris mereka adalah 58, masih jauh dibawah KKM yaitu 70. Data tersebut didapatkan dalam pembelajaran Bahasa Inggris dengan materi formal invitation.

Untuk itu, dibutuhkan strategi baru yang dapat membangkitkan semangat belajar siswa, sehingga kemampuan membaca pemahaman Bahasa Inggris siswa meningkat. Model pembelajaran discovery learning secara ansinkron dan sinkron sangat cocok digunakan untuk meningkatkan kemampuan membaca pemahaman Bahasa Inggris siswa.

\subsection{Rumusan Masalah}

Berdasarkan latar belakang permasalahan di atas, dapat dirumuskan permasalahan: Apakah penerapan model pembelajaran discovery learning dengan media zoom dapat meningkatkan kemampuan membaca pemahaman Bahasa Inggris siswa kelas XI PH 4 SMKN 1 Amlapura tahun pelajaran $2020 / 2021$ ?

\subsection{Tujuan Penelitian}

Berdasarkan rumusan masalah di atas, tujuan penelitian ini adalah untuk mengetahui sejauh mana penerapan model pembelajaran discovery learning dengan media zoom dapat meningkatkan kemampuan membaca pemahaman Bahasa Inggris siswa kelas XI PH 4 SMKN 1 Amlapura tahun pelajaran 2020/2021.

\subsection{Manfaat Penelitian}

\subsubsection{Manfaat Teoretis}

Pembelajaran inovatif berbasis daring yang diterapkan pada penelitian ini diharapkan dapat menambah khasanah ilmu tentang strategi pembelajaran inovatif.

\subsubsection{Manfaat Praktis}

1) Bagi siswa, Jika penerapan metode pembelajaran discovery learning dengan media zoom ini berhasil maka kemampuan membaca pemahaman Bahasa Inggris siswa kelas XI SMKN 1 Amlapura akan meningkat. Selain itu, para siswa juga akan mendapat pengalaman baru dalam belajar Bahasa Inggris. Sehingga, mereka tidak akan bosan dalam belajar Bahasa Inggris yang nantinya diharapkan 
motivasi siswa akan lebih meningkat dalam belajar Bahasa Inggris secara keseluruhan, tidak hanya dalam belajar membaca pemahaman.

2) Bagi guru, hasil penelitian ini bisa dijadikan referensi dalam mengembangkan cara mengajar mereka di kelas. Sehingga cara mengajar guru yang lain bisa lebih bervariasi dan inovatif. Selain itu, guru mata pelajaran yang lain juga bisa menggunakan penelitian tindakan kelas ini sebagai bahan referensi mereka dalam melaksanakan penelitian tindakan kelas yang serupa maupun jenis penelitian yang lain.

3) Bagi Sekolah, dengan meningkatnya kemampuan guru dalam menggunakan berbagai metode pembelajaran, maka semakin meningkat pula kompetensi professional guru tersebut. Pada muaranya, peningkatan kompetensi guru tersebut akan berimbas dengan kualitas SMKN 1 Amlapura.

\section{TINJAUAN PUSTAKA}

\subsection{Pembelajaran Reading}

Menurut Leipzig (2001), "Membaca adalah proses multifaset yang melibatkan pengenalan kata, kompetensi, kelancaran, dan motivasi". Artinya pembaca harus bisa mengembangkan beberapa kemampuan dalam membaca. Kemampuan tersebut adalah pengenalan kata, kompetensi, kelancaran, dan motivasi membaca. Leipzig (2001) juga menyatakan bahwa kata pengenal di sini berarti kemampuan pembaca untuk mengidentifikasi arti kata yang dicetak. Kemudian, kompetensi disini berarti bagaimana pembaca bisa membangun pemahaman dari kata-kata tersebut. Sementara kefasihan berarti bagaimana pembacla bisa mengenali kata-kata dan memberi makna sehingga bacaannya otomatis dan akurat. Dan motivasi disini berarti bagaimana pembaca bisa membaca teks dengan senang hati dan mereka tertarik untuk membaca teks. 


\begin{abstract}
Sedangkan membaca
pemahaman menurut Mayer (2003)

merupakang- teknik untuk

meningkatkan keberhasilan siswa dalam

mengekstrak pengetahuan yang berguna

tentang teks". Ini berarti bahwa

pemahaman bacaan adalah proses

konstruksi untuk membangun makna

dari sebuah teks. Pemahaman adalah

proses konstruksi karena melibatkan

semua elemen proses membaca yang

bekerja sama untuk menciptakan

representasi teks dalam pikiran pembaca.

Selain itu, Burke, Jim (2000)

menyatakan bahwa membaca

melibatkan lebih dari satu pengenalan

kata, sehingga pemahaman sangat

penting untuk dibaca dan tanpa

pemahaman bacaan tidak ada tugas

membaca yang berlangsung dan tanpa

pemahaman tidak boleh disebut

membaca.
\end{abstract}

Mengenai definisi di atas, dapat

disimpulkan bahwa pemahaman bacaan

adalah teknik untuk meningkatkan

keberhasilan siswa dalam

menggabungkan makna sejumlah kata

dalam ingatan kerja mereka sampai ia

dapat memikirkan makna kolektif mereka.

Apalagi dalam pengajaran

bahasa Inggris di SMA, membaca adalah salah satu keterampilan dasar pembelajaran bahasa yang harus dikuasai oleh siswa. Ini adalah proses aktif yang penting bagi sebagian besar mata pelajaran dan sangat penting dalam belajar bahasa, khususnya bahasa Inggris (Depdiknas 2012). Ini melibatkan standar kompetensi dan kompetensi dasar yang kemudian diwakili oleh beberapa indikator.

Dalam penelitian ini, kemampuan membaca yang dimaksdu adalah membedakan dan menganalisis teks formal invitation termasuk fungsi sosialnya, struktur dan unsur bahasa.

\subsection{Model Pembelajaran Discovery Learning}

\subsubsection{Pengertian Pembelajaran Model} Discovery Learning

Discovery Learning adalah metode mengajar yang terjadi, dimana peserta didik tidak disuguhkan dengan pelajaran dalam bentuk akhirnya, akan tetapi diharapakan untuk mengorganisasi sendiri. Dimana permasalahan yang dimunculkan direkayasa oleh guru,agar peserta didik dapat menganalisis dan mengambil kesimpulan akhir(Abidin, 2013 : 175). Model Discovery Learning menuntun siswa untuk mengidentifikasi 126 
apa yang ingin diketahui dengan mencari informasi sendiri, kemudian siswa mengorganisasi atau membentuk (konstruktif) apa yang diketahui dan dipahami ke dalam bentuk akhir. Menurut Sani (2014: 97-98), discovery learning merupakan proses dari inkuiri. Discovery learning adalah metode belajar yang menuntut guru lebih kreatif menciptakan situasi yang membuat peserta didik belajar aktif dan menemukan pengetahuan sendiri. Maharani \& Hardini (2017: 552), discovery learning adalah proses pembelajaran yang penyampaian materinya tidak utuh, karena model discovery learning menuntut siswa terlibat aktif dalam proses pembelajaran dan menemukan sendiri suatu konsep pembelajaran.

\subsubsection{Langkah-Langkah Model Discovery Learning}

Darmadi, (2017: 114-117) terdapat prosedur yang harus digunakan dalam mengaplikasikan model discovery learning, yaitu (a) stimulation (pemberian rangsangan); (b) problem statement (identifikasi masalah); (c) data collection (pengumpulan data); (d) data processing (pengolahan data); (e) verification (pembuktian); dan (f) generalization (menarik kesimpulan).

1. Stimulation (Stimulus)

Menyajikan bahan kajian di awal, contoh berupa potensi daerah setempat yang berkaitan dengan konsep geografi.

2. Problem Statement (Identifikasi Masalah)

Mengidentifikasi potensi daerah satu per satu.

3. Data Collecting (Mengumpulkan data)

Mencari dan mengumpulkan data tentang potensi daerah setempat dari sumber lain (internet, observasi atau majalah dll).

4. Data Processing (Mengolah data) Upaya mengolah potensi daerah setempat melalui berbagai sumber referensi/wawancara pakar ahli.

5. Verification (Memverivikasi) Membandingkan hasil diskusi antar kelompok untuk mendapatkan informasi dan solusi terbaik dalam memajukan potensi daerah

6. Generalization (Menyimpulkan)

Menyimpulkan hasil diskusi dari kajian potensi daerah setempat. Jadi model discovery learning di atas membuat siswa menemukan hal baru terhadap suatu fenomena dan $1<1$ 
bagaimana tindak lanjut ke depannya.

Dalam hal ini kajian yang dibahas tentang potensi daerah.

\subsubsection{Kelebihan dan Kekurangan Model Discovery Learning}

Tidak ada model atau pendekatan pembelajaran yang benar-benar sempurna. Setiap model pembelajaran atau pendekatan, atau strategi pembelajaran mempunyai kelebihan dan kekurangannya masing-masing, karena itulah, memahami setiap model, teknik, pendekatan atau strategi itu sangat penting sehingga Bapak dan Ibu Guru dapat memilih yang paling sesuai untuk suatu pembelajaran yang aka dilaksanakan di kelasnya.

Berikut ini merupakan kelebihankelebihan yang dimiliki discovery learning (pembelajaran penemuan).

a. Mendukung partisipasi aktif pembelajar dalam proses pembelajaran.

b. Menumbuhkan rasa ingin tahu pembelajar

c. Memungkinkan perkembangan keterampilan-keterampilan belajar sepanjang hayat dari pembelajar.

d. Membuat pengalaman belajar menjadi lebih bersifat personal e. Membuat pembelajar memiliki motivasi yang tinggi karena memberikan kesempatan kepada mereka untuk melakukan eksperimen dan menemukan sesuatu untuk diri mereka sendiri.

f. Membangun pengetahuan berdasarkan pada pengetahuan awal yang telah dimiliki oleh pembelajar sehingga mereka dapat memiliki pemahaman yang lebih mendalam.

g. Mengembangkan kemandirian dan otonomi pada diri pembelajar

h. Membuat pembelajar bertanggungjawab terhadap kesalahan-kesalahan dan hasilhasil yang mereka buat selama proses belajar

i. Merupakan cara belajar kebanyakan orang dewasa pada pekerjaan dan situasi kehidupan nyata

j. Merupakan suatu alasan untuk mencatat prosedur-prosedur dan temuan-temuan - seperti mengulang kesalahan-kesalahan, sebagai suatu cara untuk menganalisis apa yang telah terjadi, dan suatu cara untuk 
mencatat atau merekam temuan yang luar biasa.

k. Mengembangkan keterampilanketerampilan kreatif dan pemecahan masalah

1. Menemukan hal-hal baru yang menarik yang belum terbayang sebelumnya setelah pengumpulan informasi dan proses belajar yang dilakukan Sementara itu, kelemahankelemahan pada discovery learning (DL atau pembelajaran penemuan) adalah sebagai berikut:

a. kadangkala terjadi kebingungan pada para pembelajar ketika tidak disediakan semacam kerangka kerja, dan semacamnya.

b. terbentuknya miskonsepsi

c. pembelajar yang lemah mempunyai kecenderungan untuk belajar di bawah standar yang diinginkan, dan guru seringkali gagal mendeteksi pembelajar semacam ini (bahwa mereka membutuhkan remedi dan scaffolding).

\subsection{Pembelajaran dengan Zoom}

Pembelajaran online adalah pembelajaran melalui internet dimana siswa dan guru terpisah secara tempat, bahkan waktu. Ciri-ciri pembelajaran online yaitu pertumpu pada kemandirian peserta didik dalam belajar, penggunaan media elektronik berbasis komputer, pemanfaatan berbagai fungsi media elektronik sehingga disebut sebagai multimedia, dan penggunaan software, hardware dan jaringan internet. Kunci sukses dalam suatu kelas online bukan pada "teknologi apa" yang digunakan, tetapi "bagaimana teknologi" itu digunakan dan informasi apa yang dikomunikasikan menggunakan teknologi tersebut (Yunus, 2008).

Pembelajaran online bisa dilakukan dengan dua cara yaitu asinkron dan sinkron. Pembelajaran asinkron adalah pendekatan belajar mandiri dengan interaksi asinkron untuk mendorong pembelajaran. Email, papan diskusi online, Wikipedia, dan blog adalah sumber daya yang mendukung pembelajaran asinkron. Beberapa kegiatan pembelajaran asinkron yang umum berinteraksi dengan sistem manajemen kursus seperti Blackboard, Moodle untuk pengiriman kursus, berkomunikasi menggunakan email, memposting di forum diskusi dan 
membaca artikel. Selain itu, penting untuk menjaga umpan balik tepat waktu dan komunikasi yang jelas untuk melibatkan siswa dalam pembelajaran. Secara keseluruhan, pembelajaran asinkron memberikan keuntungan seperti kenyamanan, fleksibilitas, lebih banyak interaksi dan untuk melanjutkan tanggung jawab kehidupan pribadi dan professional

(https://id.bccrwp.org/compare/differen ce-between-synchronous-andsynchronous-learning/).

Sementara itu, pembelajaran yang sinkron, pembelajaran yang berlangsung dimana peserta didik dan instruktur berada di tempat yang sama pada waktu yang sama. Ini mirip dengan kelas tatap muka. Ini telah menjadi populer karena membantu meminimalkan tantangan dalam pendidikan online. Salah satu contoh pembelajaran sinkron adalah ketika siswa dan instruktur berpartisipasi dalam kelas melalui alat konferensi web. Ini menciptakan ruang kelas virtual yang memungkinkan siswa mengajukan pertanyaan dan para guru menjawabnya secara instan. Secara keseluruhan, pembelajaran yang sinkron memungkinkan siswa dan guru untuk berpartisipasi dan belajar secara langsung dan untuk terlibat dalam diskusi langsung (https://id.bccrwp.org/compare/differen ce-between-synchronous-andasynchronous-learning/).

Jadi, dapat disimpulkan bahwa perbedaan antara pembelajaran sinkron dan asinkron adalah bahwa pembelajaran sinkron melibatkan sekelompok siswa yang terlibat dalam pembelajaran pada saat yang sama mirip dengan kelas virtual sedangkan pembelajaran asinkron melibatkan pembelajaran yang berpusat pada siswa mirip dengan pendekatan belajar mandiri yang mirip dengan pendekatan belajar mandiri dengan sumber belajar online yang diperlukan.

Penelitian ini sesungguhnya menggunakan dua media pembelajaran yaitu online asinkron dan sinkron. Namun dalam penerapan model discovery learning, media sinkron melalui zoom digunakan.

Applikasi zoom merupakan layanan berupa software. Zoom menjadi salah satu aplikasi yang banyak digunakan orang-orang saat physical distancing karena pandemi virus corona COVID-19. Zoom didirikan oleh Eric Yuan, salah satu jutawan yang masuk dalam daftar orang terkaya di dunia versi 130 
Forbes yang berasal dari provinsi Shandong, Cina.

Zoom merupakan salah satu aplikasi yang menjadi favorit para pendidik untuk mengajar face to face secara virtual. Zoom bisa menjadi alternatif untuk mengobati kerinduan siswa kepada gurunya, dan begitu sebaliknya.

Platform ini merupakan aplikasi meeting online dengan konsep screen sharing yang bisa penggunanya bertatap muka dengan lebih dari 100 orang partisipan. Tidak hanya di $P C$ atau laptop, aplikasi ini juga bisa diunduh di smartphone.

Beberapa kelebihan pembelajaran melalui Zoom Meeting di antaranya sebagai berikut.

1. Suasana Seperti di Kelas.

Hal ini terjadi karena kita bisa melihat wajah teman dan guru dalam video siaran langsung, sehingga suasananya terasa seperti belajar di ruang kelas.

2. Bisa Melihat Presentasi.

Presentasi yang disiarkan di kelas, bisa juga diperlihatkan kepada peserta didik di sini. Selain itu, power point bisa dicoret - coret oleh siapa saya yang bergabung dalam kelas. Hal ini membantu peserta didik supaya mudah paham materi.

3. Kualitas Video yang Bagus

Vidio siaran langsung pada aplikasi ini, memiliki kualitas yang bagus, gambarnya jernih, dan suaranya pun jelas.

\subsection{Penelitian yang terkait}

Penelitian menggunakan model discovery learning sudah pernah dilakukan, seperti penelitian yang dilakukan Doni Setiawan Pramono pada tahun 2018. Penelitian tersebut bertujuan untuk meningkatkan keaktifan dan kompetensi siswa pada mata pelajaran Perawatan Kelistrikan Kendaraan Ringan kelas XI TKR 3 di SMK Negeri 2 Yogyakarta melalui penerapan metode pembelajaran discovery learning. Subjek penelitian ini adalah siswa kelas XI TKR 3 SMK Negeri 2 Yogyakarta Tahun Ajaran 2017/2018 yang berjumlah 31 siswa. Teknik pengumpulan data pada penelitian ini menggunakan observasi untuk pelaksanaan pembelajaran dan keaktifan siswa, tes untuk kompetensi kognitif, dan dokumentasi. Indikator keberhasilan penelitian ini sebesar lebih dari 70\% keaktifan siswa dan 75\% siswa mencapai KKM sebesar 76. Hasil penelitian menunjukkan bahwa melalui

LAMPUHYANG Vol. 12 No.2 Juli 2021

p-ISSN : 2087-0760; e-ISSN: 2745-5661 
penerapan metode pembelajaran Discovery Learning dapat meningkatkan keaktifan dan kompetensi siswa pada mata pelajaran Perawatan Kelistrikan Kendaraan Ringan. Hal tersebut dapat dilihat dari: (1) adanya peningkatan keaktifan siswa pada tiap siklus. Keaktifan siswa pada siklus I sebesar $40.13 \%$, dan siklus II sebesar $76.16 \%$; (2) adanya peningkatan ratarata kelas dan ketuntasan belajar siswa. Rata-rata kelas pada siklus I sebesar 75.74, dan siklus II sebesar 87.33. Ketuntasan belajar siswa yang diukur dengan tes kompetensi kognitif pada siklus I sebesar $67.74 \%$, dan siklus II sebesar $93.33 \%$.

Penelitian menggunakan zoom meeting sebagai media pembelajaran juga sudah dilakukan oleh Danin Haqien pada tahun 2020. Penelitian ini dilakukan untuk mengetahui seberapa efektifnya penggunaan aplikasi Zoom Meeting terhadap para mahasiswa di Jakarta dan Depok ketika pandemi COVID-19. Penelitian ini bersifat kualitatif dan menggunakan metode grounded theory. Teknik pengumpulan data dilakukan dengan wawancara melalui Google Form dan Whatsapp kepada tiga puluh dua mahasiswa Universitas di Jakarta dan Depok. Hasil penelitian ini, menunjukkan bahwa penggunaan aplikasi Zoom Meeting tidak begitu efektif bagi para mahasiswa Universitas di Jakarta dan Depok. Tetapi, aplikasi Zoom Meeting lebih baik karena dalam aplikasi Zoom Meeting komunikasi antara individu dilakukan secara lisan dibandingkan penggunaan aplikasi pembelajaran yang melakukan kegiatan komunikasi secara tertulis menurut teori komunikasi pendidikan.

\section{METODE PENELITIAN}

Penelitian ini merupakan penelitian tindakan yang bertujuan untuk mengetahui sejauh mana penerapan model pembelajaran discovery learning dengan media zoom dapat meningkatkan kemampuan membaca pemahaman Bahasa Inggris siswa kelas XI PH 4 SMKN 1 Amlapura tahun pelajaran 2020/2021. Penelitian ini dilakukan dalam 2 (dua) siklus. Subjek penelitian ini adalah siswa kelas XI PH 4 SMKN 1 Amlapura tahun pelajaran 2020/2021 yang berjumlah 32 orang. Objek penelitian ini adalah peningkatan kemampuan membaca siswa SMKN 1 Amlapura kelas XI PH 4 dengan menggunakan model pembelajaran discovery learning dengan media zoom 
meeting. Metode pengumpulan data dianalisis dengan menggunakan analisis dilakukan dengan observasi dan tes. Data diskriptif kuantitatif yang berlangsung yang telah terkumpul dari hasil tes setiap akhir siklus.

Data hasil belajar siswa diolah dengan menentukan nilai berikut:

Nilai rata-rata hasil tes (mean) dengan rumus:

$\overline{\mathrm{X}}=\frac{\text { jumlah nilai mahasiswa keseluruhan }}{\text { jumlah mahasiswa }}$

Keterangan:

$\overline{\mathrm{X}}=$ nilai rata-rata mahasiswa

(Sutrisno Hadi, 2000 : 39)

Daya serap mahasiswa diperoleh dengan rumus:

$\mathrm{DS}=\frac{\text { nilai rata-rata kelas }}{\text { nilai tertinggi }} \times 100 \%$

Keterangan:

DS = Daya Serap

(Sudijono, 2006:81)

\section{HASIL DAN PEMBAHASAN}

\subsection{Hasil Penelitian}

Berdasarkan hasil pengolahan

data mulai refleksi awal, siklus 1 dan siklus 2, dapat dilihat terjadinya peningkatan kemampuan membaca pemahaman Bahasa Inggris siswa kelas

\begin{abstract}
XI PH 4 SMKN 1 Amlapura. Untuk lebih jelasnya, berikut disajikan rangkuman kemampuan membaca pemahaman Bahasa Inggris yang diperoleh pada refleksi awal sampai siklus II.
\end{abstract}

Tabel 01

Rangkuman Kemampuan Membaca Pemahaman Bahasa Inggris pada Refleksi Awal, Siklus I, dan Siklus II

\begin{tabular}{|l|c|c|c|c|c|c|}
\hline \multirow{2}{*}{ No } & \multicolumn{3}{|l|}{ Nilai Refleksi Awal } & \multicolumn{2}{l|}{ Nilai Siklus I } & \multicolumn{2}{l|}{ Nilai Siklus II } \\
\cline { 2 - 7 } & Rata-rata & Ketuntasan & Rata-rata & Ketuntasan & Rata-rata & Ketuntasan \\
\hline 1 & 58 & $48 \%$ & 70,40 & $80,76 \%$ & 71,11 & $81,48 \%$ \\
\hline
\end{tabular}




\subsection{Pembahasan}

Data awal yang diperoleh pada saat refleksi awal dengan rata-rata 58 menunjukkan bahwa kemampuan siswa XI PH 4 SMKN 1 Amlapura dalam membaca pemahaman Bahasa Inggris tergolong masih rendah. Dengan kondisi tersebut, diperlukan upaya untuk meningkatkan kemampuan siswa, terlebih lagi dalam situasi pandemik, dimana siswa belajar dari rumah. Model pembelajaran discovery learning secara asinkron dan sinkron sangat cocok digunakan untuk meningkatkan kemampuan membaca pemahaman

Bahasa Inggris siswa.

Berdasarkan hasil tersebut dapat dilihat bahwa kurva nilai siswa normal, dimana rata-modus nilai siswa yaitu 80. Hanya 1 orang siswa mendapatkan nilai 90 , dan 1 orang mendapatkan nilai 30. Nilai yang bervariasi tersebut, menjadi salah satu indikator bahwa soal yang dibuat sudah HOTS. Hasil nilai ini juga sudah meningkat dari refleksi awal yang dilakukan oleh guru, dimana rata-rata nilai siswa yaitu 58 dan di akhir siklus 1 menjadi 70,40. Dan ketuntasan siswa juga meningkat dari $48 \%$ menjadi
$80,76 \%$ di siklus 1. Namun perlu dilakukan siklus 2 untuk melihat konsistensi nilai siswa.

Pada siklus II, data menunjukkan nilai siswa cenderung konsisten. Peningkatan hanya terjadi sedikit, dimana rata-rata siswa berubah dari 70,40 di siklus I menjadi 71,11 di siklus II dan ketuntasan berubah dari $80,76 \%$ di siklus I menjadi $81,48 \%$ di siklus II. Hal tersebut membuktikan bahwa penggunaan model discovery learning dengan media zoom efektif untuk menjawab permasalahan dalam penelitian ini.

Adapun kelebihan dari digunakannya model discovery learning dengan media zoom, yaitu:

1. Guru dan siswa bisa bertatap muka. Meskipun secara virtual, namun hal tersebut sangat mengobati kerinduang siswa terhadap guru dan begitu pula sebaliknya.

2. Suasana belajar mirip belajara di kelas. Guru bisa mengontrol siswa dan memastika siswa belajar, karena dapat dipantau. Guru bisa dengan mudah juga menunjukkan power point atau materi/contoh 
dengan menggunakan fasilitas sharescreen.

3. Mengasah kemampuan literasi digital siswa. Siswa yang belum terbiasa menggunakan applikasi sinkron dalam pembelajaran menjadi terbiasa.

4. Guru tidak mendominasi pembelajaran. Dengan model discovery learning siswa dibimbing untuk menemukan sendiri konsep yang dipelajari.

5. Siswa generasi $Z$ sangat menyukai hal berbau internet dan digital, sehingga dengan menggunakan zoom dalam pembelajaran, siswa menjadi lebih bersemangat dalam belajar.

\section{PENUTUP}

Berdasarkan hasil analisis data dan pembahsan hasil penelitian yang telah diuraikan pada bab sebelumnya, maka dapat disimpulkan bahwa penerapan model pembelajaran discovery learning dengan media zoom dapat meningkatkan kemampuan membaca pemahaman Bahasa Inggris siswa kelas XI PH 4 SMKN 1 Amlapura tahun pelajaran 2020/2021.
Berdasarkan simpulan di atas, dapat dikemukakan saran-saran sebagai berikut.

1. Siswa, hendaknya lebih semangat belajar menggunakan berbagai sumber secara mandiri. Dalam hal ini model discovery learning dapat membantu siswa menemukan sendiri konsep yang ingin dipelajari dan mengasah keterampilan siswa dalam membaca pemahaman pun dalam literasi digital.

2. Guru dalam proses belajar mengajar diharapkan menggunakan model pembelajaran discovery learning dengan media zoom sebagai salah satu alternatif pembelajaran untuk meningkatkan keterampilan membaca siswa khususnya dalam pembelajaran daring

3. Kepala Sekolah diharapkan menganjurkan kepada guru-guru untuk mempergunakan model pembelajaran discovery learning dengan media zoom untuk meningkatkan prestasi belajar siswa, sehingga menghasilkan 
output siswa yang lebih baik, khususnya dalam mata pelajaran bahasa Inggris serta mata pelajaran lain pada umumnya secara daring.

4. Peneliti lainnya, hendaknya para peneliti selanjutnya mencoba menerapkan pada sampel yang lebih luas dan meneliti masalah lebih dalam, sehingga diperoleh hasil penelitian yang lebih baik.

\section{DAFTAR PUSTAKA}

Arikunto, S. (2016). Prosedur Penelitian Suatu Pendekatan Praktik. Jakarta: Rineka Cipta.

Darmadi. (2017). Pengembangan model dan metode pembelajaran dalam dinamika belajar siswa. Yogyakarta: CV Budi Utama.
Maharani, Y. B., \& Hardini, I. T. A. (2017). Penerapan model pembelajaran discovery learning berbantuan benda konkret untuk meningkatkan hasil belajar IPA. Jurnal Mitra Pendidikan, 1 (5), 249-561.

Sani, R. (2014). Pembelajaran saintifik untuk implementasi kurikulum 2013. Jakarta: PT. Bumi Aksara.

Sanjaya, D. H. W. (2016). Penelitian tindakan kelas. Prenada Media.

Sulfemi, W. B. (2019). Penerapan Model Pembelajaran Discovery Learning Meningkatkan Motivasi Dan Hasil Belajar Pendidikan Kewarganegaraan. Jurnal Rontal Keilmuan Pancasila dan Kewarganegaraan, 5(1).

Yunus, M. 2018. Learning Beyond the Wall (PPt). Universitas Terbuka.

https://id.bccrwp.org/compare/differenc e-between-synchronous-andasynchronous-learning/ 